\title{
Editorial Introduction: Assessing Deng Xiaoping's Legacy
}

Deng Xiaoping has been one of the world's pre-eminent leaders of the late 20th century. Deng's impact will be felt well into the next century as China looms as the world's next superpower as a result of his reforms.

Deng's life spanned the century, involving him in many of the major events of modern China's revolutionary development, although his activities were primarily noticeable during the 1980s and early 1990s. Deng was born during the waning years of the last imperial dynasty. He had a fairly typical peasant upbringing in rural Sichuan before being dispatched to bustling Chongqing and then abroad for study. Like many other would-be revolutionaries, Deng experienced the proletarian life of Paris and received Comintern training in Moscow. From his return to China in 1927 until the Chinese Communist Party (CCP) seized power in 1949, Deng's exploits were the militant revolutionary activities of the time: urban underground organization; peasant uprisings; public propaganda and political indoctrination among Red Army troops; the Long March; and numerous battle campaigns during the anti-Japanese and civil wars. After 1949 Deng served initially as a regional administrator in his native south-west, before moving on to a succession of key Party, government and military posts in Beijing prior to the Cultural Revolution. By 1954 he was one of the inner circle of CCP leaders, and as such had a hand in virtually every key policy and event from 1954 to 1966 . Like so many other CCP elites, he came under vicious attack during the Cultural Revolution and endured six years in internal exile. The mid-1970s saw him rise again to the pinnacle of power only (again) to fall suddenly just before Mao's death. With the fourth political "rehabilitation" of his career in 1977 Deng set about deconstructing the Maoist state and constructing his comprehensive programme to reform China and bring it into the front ranks of world powers.

Deng's career was certainly not without its blemishes, the Tiananmen massacre being the most noteworthy. His legacy will be complex and his historical verdict no doubt mixed. Yet there is no denying that Deng was responsible for a monumental transformation of one-fifth of humanity, awakening China from its socialist slumber with the prospect of an unprecedented future.

Deng Xiaoping pursued many goals during his lifetime, but none more central nor persistently than strengthening the Chinese nation-state. Deng was a staunch nationalist who sought to restore China's wealth and power. This quest of Deng's was not unlike that of previous. Chinese reformers during the 19th and 20th centuries: creation of a modern industrial base; transformation of China's agrarian social structure; attainment of a materially comfortable standard of living for the populace; reclaimed national independence, dignity, and freedom of manoeuvre in foreign relations; a strong national defence and maintenance of territorial integrity around China's borderlands; and attainment of great power status. In these respects, Deng's vision for China shares an essential 
continuity along a historical spectrum of Chinese reformers dating from the late Qing reformers Li Hongzhang and Kang Youwei. Deng was not the first Chinese leader with these goals during this century, but he was the most successful in realizing them.

Deng Xiaoping inherited from Mao Zedong a stagnant economy, alienated society and paralysed polity. He will bequeath to his successors a robust economy and rejuvenated society, but antiquated political system. China's political system is antiquated partly for reasons common to Leninist party-states, but also because of Deng's steadfast refusal to create meaningful channels of political participation for China's citizenry. In significant ways Deng was a true Leninist. Unlike Mao who assaulted the commanding heights and tore asunder the Communist apparat during the Cultural Revolution, Deng sought to rebuild the party-state. Deng believed, like other Chinese reformers before him, that a strong state which monopolized political power was essential to economic development. His view was reinforced by the East Asian developmental model.

Yet, at the same time as Deng rebuilt the party-state from its fractured condition of the Cultural Revolution, he also sowed the seeds of its potential demise. His economic reform programme and the autonomy from state control that he created for Chinese from many walks of life inexorably decreased the Party's previous hegemony. In the wake of Tiananmen Deng and the Chinese leadership sought to refurbish the instruments of Orwellian state power - subjecting the society to considerable coercion, propaganda and economic austerity - only to realize that these instruments had dulled as a result of the 1980s reforms. From the collapse of Communist regimes across the globe in 1989-91 Deng drew the lesson that only material gain can ultimately save socialism. Of course, he also concluded that tight political control and the loyal support of the security services were important elements, but without material gain no degree of coercion could ensure the Party's survival. Consequently, in 1992 Deng reignited radical economic reform. The results were impressive indeed: 12.8 per cent GNP growth in 1992. Foreign direct investment poured into China at unprecedented levels. But overheating, inflation, corruption and many other negative manifestations resulted. At the time these articles were written the full impact of this latest reformist phase has yet to be felt - either for the Communist Party or for Deng himself.

Deng Xiaoping ruled very differently from Mao Zedong. Deng did not rely on coercion, charisma or ideology, but preferred to rule through formal Party institutions and Leninist norms. Only late in life did he, like Mao, grow distrustful of the party-state he had created. When this occurred in 1991-92, like Mao, Deng circumvented his chosen successors and the bureaucracy by taking his case directly to the people during his famous Southern Tour (nan xun). Not a populist by nature, Deng was acting out of frustration with his chosen successors.

At the same time, it must be recognized that (unlike Mao) Deng Xiaoping trusted in the entrepreneurial spirit in Chinese culture, and did much to remove state strictures from people's lives. In this sense he 
shares a legacy with free-marketeers Ronald Reagan and Margaret Thatcher. Getting the government "off the backs" of average Chinese, in order to free their essential commercial instincts, will be one of Deng's most enduring legacies. He rolled back much of the intrusive apparatus that had intimidated a vast nation and provided the stimulus for the realization of the Napoleonic prophecy of the awakened Chinese giant. In doing so, however, he unleashed powerful centrifugal forces in society that are progressively undermining Leninist rule and Communist Party control. In this respect Deng may be remembered more like Mikhail Gorbachev. This is true of many the world's great reformers, who satisfy the people's cravings only to create new and insatiable desires. Deng's lasting contribution was to stimulate the revolution of rising expectations.

One does not know when Deng Xiaoping will "go to meet Marx" (as he once noted in meeting a visiting dignitary), but it is not too early to offer a preliminary assessment of his life and times. Such an assessment is, of course, conditioned by its temporal perspective. An assessment of Deng in 1993 varies considerably from what one would have written in the aftermath of the 1989 Beijing massacre (for which Deng was primarily responsible), at the height of the Cultural Revolution, or during the Long March.

History and historians will ultimately cast judgments on Deng Xiaoping, and therefore the articles that follow hold no pretence of definitiveness or ultimate verdict, but at the same time offer careful, comprehensive analysis and reasoned judgments by some of the world's leading China specialists and Deng-watchers. They are the product not only of lengthy and detailed research that draws upon unprecedented sources and data, but also grow out of an intensive three-day workshop held at the School of Oriental and African Studies (University of London) in May 1992, and at the 1993 annual meeting of the Association of Asian Studies in Los Angeles.

The eminent political scientist and sinologist Lucian W. Pye opens the Special Issue with an introductory discussion of Deng Xiaoping in the context of Chinese political culture, and Benjamin Yang follows with a detailed biographical study of Deng's pre-1949 years. The subsequent articles are organized along various key dimensions of Deng Xiaoping's professional persona: politician (David Shambaugh), economist (Barry Naughton), social reformer (Martin King Whyte), soldier (June Teufel Dreyer) and statesman (Michael Yahuda).

The China Quarterly is pleased to bring this Special Issue on' Deng Xiaoping to its readership. It is hoped that, while preliminary, the analyses will contribute to a broader understanding of Deng's life and times, and begin to assess his place in the scales of history.

DaVid Shambaugh 